\title{
INNOVATIONS IN THE MARKET OF FINANCIAL SERVICES OF THE DIGITAL ECONOMY: GENERAL TRENDS AND PROSPECTS
}

\section{IHНОВАЦІЇ НА РИНКУ ФІНАНСОВИХ ПОСЛУГ ЦИФРОВОЇ ЕКОНОМІКИ: ЗАГАЛЬНІ ТЕНДЕНЦІї ТА ПЕРСПЕКТИВИ}

\begin{abstract}
The rapid development of the digital economy and digital society through the use of new technologies has a significant impact on the financial sector, the institutions of which mediate almost all transactions of economic entities. Financial innovations are becoming an important factor in changes in financial markets. The latter appear in the financial services market under the influence of demand and supply factors, the former expand affordability and inclusiveness, while the others combine financial products, services within the financial ecosystem or marketplace. Technologies that change the Fintech industry are grouped into several separate groups, the application of these technologies changes the institutional environment, and the latter singles out financial regulators that use regulatory and supervisory technologies. The global Fintech market has significant potential and a number of new opportunities in the future. In Ukraine, the Fintech industry is actively developing, while the main problems of the domestic Fintech market are insufficient funding, a narrow area of specialization, insufficient level of cooperation with banks.

Key words: digital economy, financial innovations, financial market, financial technologies FinTech companies, financial marketing, cognitive technologies, distributed computing, technologies in the field of cybersecurity, disruptive innovations, digital format.
\end{abstract}

Быстрое развитие цифрровой экономики и цифррового общества через использование новейших технологий существенно влияет и на фринансовую сфреру, институты которой опосредствуют почти все трансакции экономических субъектов. Весомым фрактором изменений на финансовых рынках становятся фринансовые инновации. Последние на рынке финансовых услуг появляются под влиянием фракторов спроса и фракторов предложения, первые расширяют фринансовую доступность и инклюзивность, вторые - объединяют фринансовые продукты, сервисы и услуги в рамках финансовой экосистемы или маркетплейсу. Технологии которые меняют отрасль Финтех объединяют в несколько отдельных групп, применение этих технологий меняет институциональная среда, а в последнем выделены финансовых регуляторов, которые используют регулятивные и надзорные технологии. Глобальный Финтех рынок имеет значительный потенциал и в перспективе челый ряд новых возможностей. В Украине Финтех индустрия активно развивается, при этом основные проблемы отечественного Финтех рынка - недостаточное сринансирование, узкая плоскость специализаций, недостаточный уровень сотрудничества с банками.

Ключевые слова: чисрровая экономика, финансовые инновации, фринансовый рынок, финансовые технологии, Финтех компании, фринансовый маркетинг, когнитивные технологии, распределенные вычисления, технологии в области кибербезопасности, дизруптивные инновации, цифровой формат.

National University

Розвиток цифррової економіки та цифррового суспільства виступає сьогодні найбільш вагомим світовим трендом. Процеси цисрровізації особливо важливі для фрінансової ссрери, інститути якої «пропускають» через себе майже всі трансакції економічних суб'єктів. Сучасні інноваціїу у фрінансовій сфері впливають на розвиток та модифрікацію як структурних складових економіки так і всіх сфер життєдіяльності суспільства в цілому. Цифррова економіка змістовно визначає діяльність своїх суб'єктів через повсякденні онлайн-зв'язки між ними, срормуючи нову системно-цисррову гіперпов'язаність, тобто зростаючий взаємозв'язок між економічними суб'єктами на основі новітніх технологій. При цьому вагомим чинником змін виступають інновації. Сектор ррінансових послуг розвивається у світі під значним впливом новітніх цисррових технологій. Дослідження фрінансових інновацій пояснюють останні, виходячи з мотиваційних теорій у двох аспектах: по-перше, активні нововведення новаторів, які узгоджуються з потребами споживачів як відповідь на вимоги попиту, а, по-друге, пасивні нововведення, щоб уникнути несприятливих впливів навколишнього середовища-інновації, які узгоджуються з пропозицією. Фінтех в останні роки розвивається високими темпами як одна із найбільш перспективних галузей економіки. Відкриваються можливості як з боку пропозиції - об'єднувати срінансові продукти, сервіси і послуги в рамках фрінансової екосистеми або маркетплейсу, так і з боку попиту - розширювати фрінансову доступність та інклюзивність внаслідок вирівнювання можливостей для різних категорій споживачів. Наука і практика основні технології та технологічні концепції, які змінюють індустрію Фінтех, як правило, об'єднує кілька окремих груп, когнітивні технології, розподілені обчислювання, технології в області кібербезпеки. Викликані застосуванням цих технологій маситабні зміни у сфрері фрінансових послуг вимагають змін інституціонального середовища, в якому важливу роль відіграє діяльність фрінансових регуляторів з боку держави, які активно використовують новітні регулятивні та наглядові технології. Дослідження глобального Фінтех ринку свідчать про значний потенціал його розвитку та появу цілого ряду нових можливостей у перспективі. В Україні Фінтех індустрія активно розвивається, основні тренди цього розвитку співпадають із загальносвітовими, проте основною проблемою національного ринку виступає незначне фрінансування Фінтех компаній (стартапів), вузька «гамма» спеціалізацій українського Фінтех х сектору, недостатній рівень співпраці з українськими банками.

Ключові слова: цифррова економіка, фрінансові інновації, фрінансовий ринок, фрінансові технології, Фінтех компанії, фрінансовий маркетинг, когнитивні технології, розподілені обчислення, технології в області кібербезпеки, дизруптивні інновації, цифрровий фрормат.

Formulation of the problem. The unpredictable rapid development of the digital economy has already become a major global trend. The world is rapidly entering the era of Industry 4.0, which involves through digitalization of virtually everything related to business. Today, the Internet, biorobots, biotechnology, artificial intelligence open up endless possibilities for the appearance of qualitatively new products and services. This means the merging of technologies that blur the boundaries between physical, digital and biological spheres. All physical assets will be integrated into the digital ecosystem together with partners involved in the value chain, especially important for the financial sector, whose 
institutions in the modern world mediate almost all transactions of economic actors. Global digitalization gives Ukraine a chance to catch up with more developed countries but if it does not quickly take advantage of these opportunities it then can become even more lagging behind.

Analysis of recent research and publications. Innovation research, including financial, development and functioning of economic and financial systems, features of the influence of innovative and financial factors on economic development are devoted to the work of many foreign and domestic scholars, among them T. Beck, S. Goshall, R. Dig, D. Emery, C. Kristensen, R. La Porta, R. Levin, H. Minski, R. Merton, G. Mintzberg, K. Peres, V. Soloviov, M. Tirol, D. Tis, L. White, L. Fedulova, J. Finnerti, A. Schleifer, J. Schumpeter. However, rapid technological changes in the modern world and the corresponding socioeconomic changes require further research in view of the possibility of new digitalization conditions.

Objectives statement. The purpose of the article is to investigate the impact of modern financial innovations on the development and modification of the structural components of the economic system, economic relations, markets, forms, and models of doing business in the context of deploying a comprehensive digitalization of the functioning of society.

Outline of the main research material.Transformational processes in the economic system of a particular state always act as the driving forces and patterns of qualitative and quantitative changes in the economy and society. The economic system forms the material basis of life and development of society, has its own laws, the logic of functioning and transformations. It is subordinated to the internal laws of macroeconomic development, which is conditioned by scientific and technological progress, trends in the development of world economic relations, shifts in the sectoral and territorial division of labor, and, finally, the qualitative state of the economy, cyclicality and the wave-like nature of its development. The digital transformation of the economy is the determining factor of the present, which extends influence on all of these aspects.

Digital economy is the economic activity that results from billions of everyday online connections among people, businesses, devices, data, and processes. The backbone of the digital economy is hyperconnectivity, which means growing interconnectedness of people, organizations, and machines that results in the Internet, mobile technology and the internet of things (IOT) and is formed under the influence of a number of factors (Table 1).

Innovations are an important driver of change. Innovation and Change are the key to finding new solutions to global, national, and local challenges. Innovation and the resulting change push the boundaries of the digital ecosystem and what it can do; it is in equal parts the most impactful and challenging driver to jumpstart. Many modern innovations have a disruptive effect. Digital Disruption are changes enabled by digital technologies that occur at a pace and magnitude that disrupt established ways of value creation, social interactions, doing business and more generally our thinking [2; 3]. Disruptive innovations are oriented on new markets, competing with lack of consumption, that is, providing benefits for the "nonconsumer", or bring with them convenience and low prices to consumers, dissatisfied with consumption.

The financial services sector is particularly affected by the transforming influence of the latest digital technologies. Startups, new technologies in the world of finance and digitalization change our

Drivers of Digital Evolution [1]

\begin{tabular}{|c|c|c|c|}
\hline $\begin{array}{c}\text { SUPPLY } \\
\text { CONDITIONS }\end{array}$ & $\begin{array}{c}\text { DEMAND } \\
\text { CONDITIONS }\end{array}$ & $\begin{array}{l}\text { INSTITUTIONAL } \\
\text { ENVIRONMENT }\end{array}$ & $\begin{array}{l}\text { INNOVATION } \\
\text { AND CHANGE }\end{array}$ \\
\hline $\begin{array}{c}\text { Access Infrastructure } \\
\text { Communications } \\
\text { sophistication and coverage; } \\
\text { security }\end{array}$ & \begin{tabular}{|} 
Consumer Capacity to \\
Engage \\
Consumer ability and \\
willingness to spend; gender \\
digital divide
\end{tabular} & $\begin{array}{c}\text { Institutions and the Business } \\
\text { Environment } \\
\text { The legal environment } \\
\text { including efficiency in } \\
\text { settling disputes, IP and } \\
\text { investor protections; and } \\
\text { Bureaucracy } \\
\end{array}$ & $\begin{array}{c}\text { Inputs } \\
\text { Financing options and } \\
\text { opportunity; start-up } \\
\text { capacity; ability to attract } \\
\text { and retain talent }\end{array}$ \\
\hline $\begin{array}{c}\text { Transaction Infrastructure } \\
\text { Access to financial } \\
\text { institutions; electronic } \\
\text { payment options }\end{array}$ & $\begin{array}{l}\text { Digital Payment Uptake } \\
\text { Degree of financial inclusion } \\
\text { and use of digital money }\end{array}$ & $\begin{array}{c}\text { Institutions and the Digital } \\
\text { Ecosystem } \\
\text { Government uptake and } \\
\text { use of ICT and digital } \\
\text { technology; telecom } \\
\text { competition } \\
\end{array}$ & $\begin{array}{c}\text { Process } \\
\text { Sophistication of business } \\
\text { practices; R\&D }\end{array}$ \\
\hline $\begin{array}{c}\text { Fulfilment Infrastructure } \\
\text { Quality of transportation } \\
\text { infrastructure; logistics } \\
\text { performance }\end{array}$ & $\begin{array}{l}\text { Digital Uptake } \\
\text { Device prevalence and } \\
\text { density; technology, Internet, } \\
\text { and mobile connection } \\
\text { uptake; digital consumption }\end{array}$ & $\begin{array}{l}\text { Institutional Effectiveness } \\
\text { and Trust } \\
\text { Transparency; } \\
\text { rule of law; } \\
\text { regulatory quality }\end{array}$ & $\begin{array}{l}\text { Output } \\
\text { Depth of mobile } \\
\text { engagement; } \\
\text { reach of innovation; use of } \\
\text { social networks and digital } \\
\text { entertainment }\end{array}$ \\
\hline
\end{tabular}


perceptions of financial institutions, their services, marketing strategies in financial markets, business models and their role in the economy as a whole.

The study of financial innovations explains the latter based on motivational theories. The generalization of the characteristics of these theories and their study in conjunction with the experience of the western countries makes it possible to determine the motivation of financial innovation in two aspects: firstly, active innovations of innovators in pursuit of profits - innovations that are consistent with needs (response to demand requirements); and secondly, passive innovations in order to avoid adverse environmental impacts - innovations that are consistent with the proposal. Specific innovation activities can be presented through the motivation of adapting to the needs (making the various services offered by the financial system cheaper and more accessible to customers and improving their quality), adaptation of the proposal and regulatory avoidance (is a component of the first two).

Information technology (IT) in financial services has traditionally been viewed as an operational detail that takes a backseat to business strategy. However, in today's technology-driven world, strategy and IT are inextricably linked. In fact, more often than not IT is now the primary catalyst of competitive advantage and strategic disruption in financial services. Every company is a technology company at its core. This is especially true in financial services.

Transformations in technology can be accomplished through interactive social, political and managerial changes. Accordingly, the changes should take place both at the level of management and organization of the firm, and at the level of the system of social and political regulation. Thus, innovation changes occur in the close relationship and interdependence of technological, financial, marketing and institutional innovations (Figure 1).

Financial innovations lead to changes in the costs and benefits of specific institutional mechanisms. That is, the embedding of technological and financial innovations in the system requires changing the conditions of its functioning - institutional changes through institutional innovations. For example, increasing financial development due to the introduction of financial innovation will lead to the demand and the emergence of higher quality law institutions and property rights institutions. The process of implementing financial innovations undeniably influenced the structure of financial systems, the ratio of its various components.

The rapid development of innovations led to the penetration of the financial sector into the system processes of other segments of the economy and the provision of financial services by nonfinancial organizations - the development of FinTech companies, individual financial services of retail companies. The spread of FinTech-industry is due to the financial crisis. In the conditions of public dissatisfaction with the banking system, the commitment to financial innovation grew.

Financial technology or FinTech is one of the most promising branches of the last years (Figure 2).

The industry was launched by a new wave of companies motivated to change the concept of payments, lending and investing through the use of advanced digital technologies, the main of which are application programming interfaces, artificial intelligence, machine learning, Big Data, distributed technologies (such as Blockchain), cloud and mobile technologies, smart contracts, cryptography and biometrics. The most breakthrough sector is the branch of payments and remittances. FinTech companies fill the business with innovative ideas and new technologies and are able to offer the full range of financial services that previously were the competence of banking institutions.

The impact of the fourth industrial revolution on business leads to inevitable shifts from the mere proliferation of digital technologies towards a more complex form of innovation. This makes all companies, especially financial, to look at ways of doing business. For some companies, the seizure of new areas of value creation may be the development of new business in adjacent segments (disintermediation of the financial sector), for others - the finding of mixed cost centers in the existing industries (financial services provided by retail companies - e-wallet, payments, provision of related services financial institutions the purchase of tickets, things, entertainment through the online banking platform). Such changes lead to the following consequences for the financial sector: expectations of financial services users are changing, improved from data that increases asset productivity, quality of financial products, new partnerships are formed as companies become aware of new forms of cooperation; operational models are transformed into digital models. In this way, opportunities which are offered on the supply side to combine financial products, services and services within the financial ecosystem or multifunctional marketplaces as a new business model, and from the demand side to expand financial affordability and inclusiveness as a result of equalization of opportunities for consumers from various income groups, the reduction of relative value and non-economic barriers to financial transactions for less wealthy clients.

Among the main technologies and technological concepts that are changing the FinTech industry, there are the following: social networks; P2P; virtual and augmented reality (VR, AR); distributed registry technology (blockchain), crypto-world, smart contracts; open APIs; open IT sources; infrastructure sharing; big data, automated data collection; machine learning, deep learning, artificial intelligence (Al); 


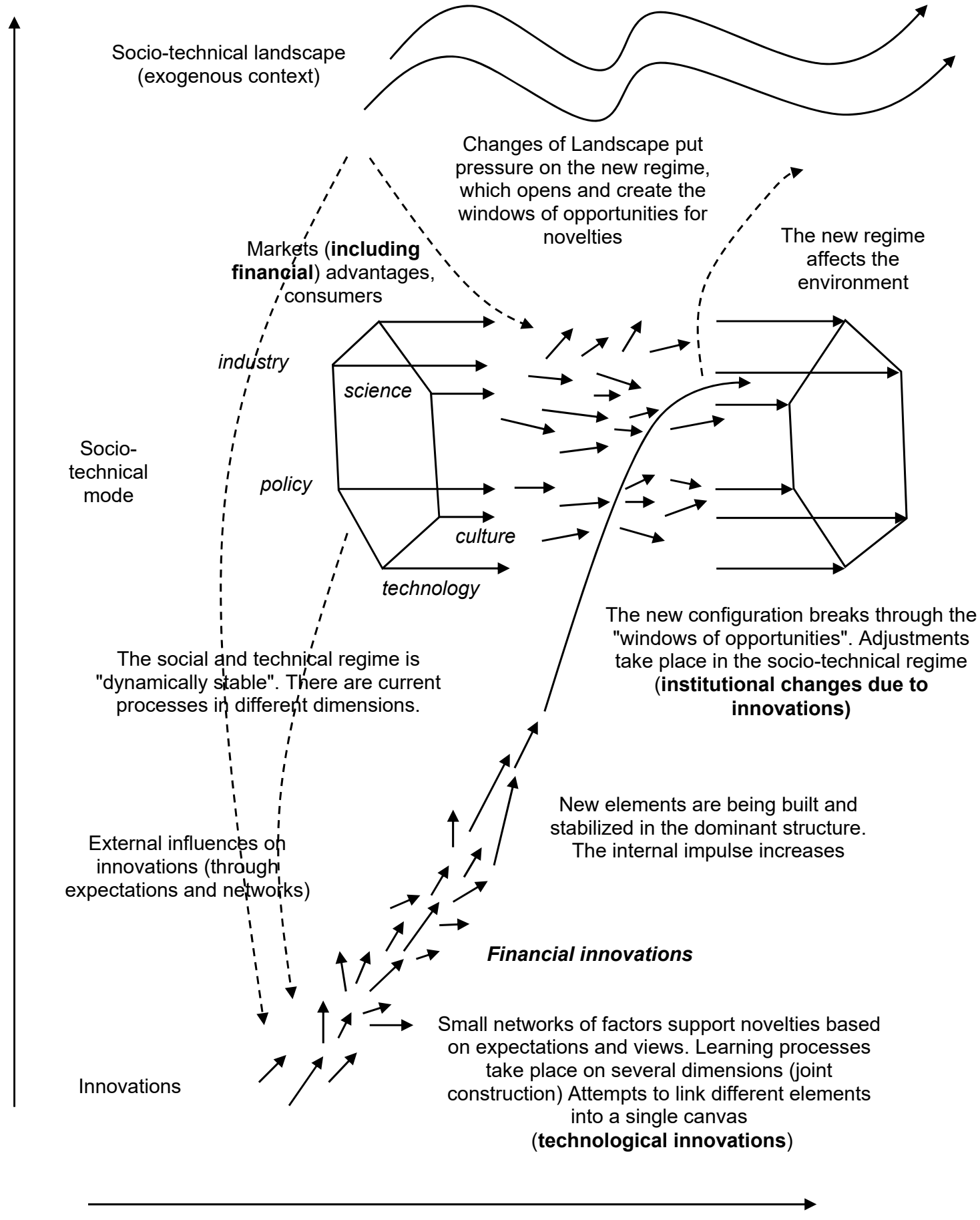

Figure 1. Innovative dynamics [4]

algotrading; smart devices (smartphones, tablets, watches); Internet of Things (IOT), sensors; NFC and other financial technologies. All these technologies can be combined into several separate groups:

- cognitive technologies that allow to perform work without human intervention and focus on automating processes that cannot be described by precise instructions. Among these technologies: artificial intelligence, big data analytics, the Internet of Things, virtual and augmented reality;

- distributed computing is associated with distributed data processing and storage and is aimed at solving the problems of exponential growth of their volume in the digital world. This group of technologies includes cloud computing and distributed registry technologies:

- cybersecurity technologies have become the most relevant in the digital economy. They increase security through remote/biometric identification and tokenization.

New solutions in the financial services market, which arise from the introduction of innovative technologies, cause in the marketing discourse influences in two sections: 


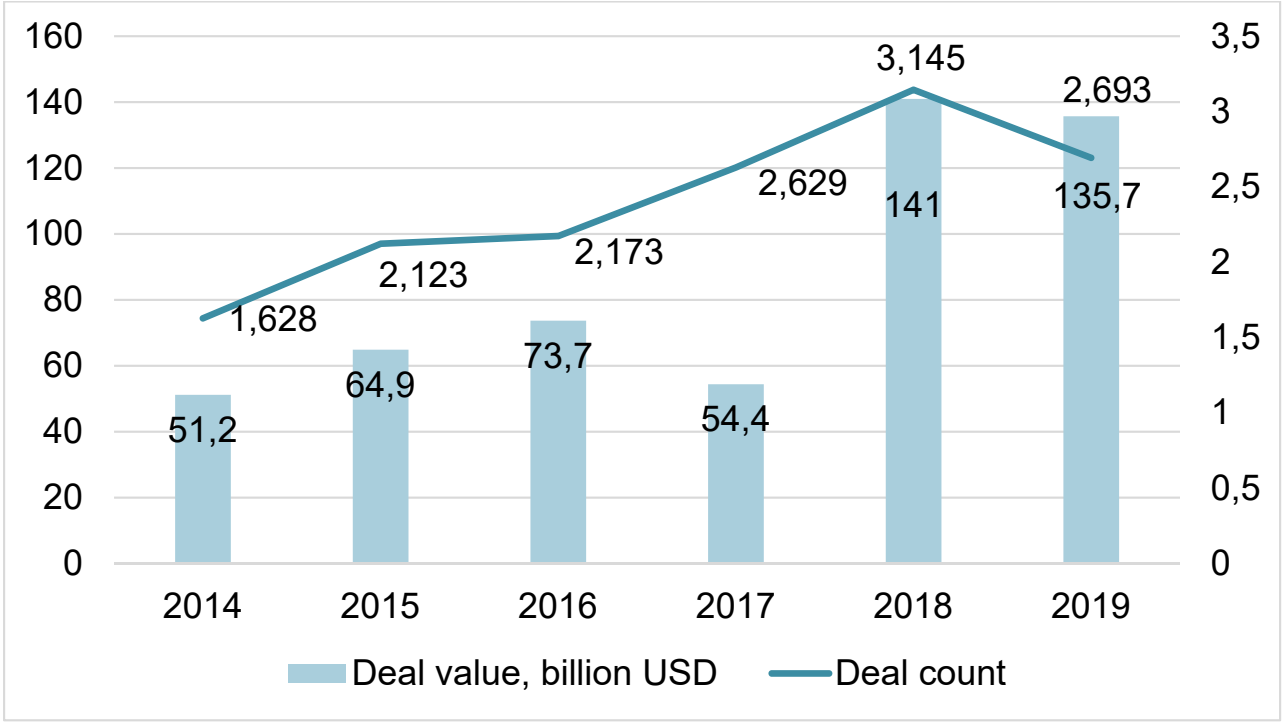

Figure 2. Total investment activity in Fintech [5]

1) improving the customer experience, either with additions to current functionality, or with completely new products, services and features;

2) in terms of market, and competition, and includes two types of effects: subversive effects (new business models, new market mechanisms, technology infrastructure sharing, etc.) and complementary effects (improvement of existing business models, hybrid services, open API).

At the intersection of these dimensions, new services and opportunities for development appear both for existing market players and for new participants, which determine the overall impact of FinTech (Table 2).

The basis of the formation of the FinTech market are the factors that determine the demand and applied technologies. Changing consumer preferences stimulate the improvement of technology, and technological progress is a driver of changing consumer preferences. However, the pace of industry development will also depend on companies' access to finance and human capital, i.e. the institutional environment.

The importance and scale of changes in financial services requires changes in the institutional environment. Financial regulators should take into account the interests of stakeholders regarding the impact of new technologies on the financial services sector, from the point of view of financial service providers, their consumers, and in terms of regulatory and supervisory compliance with the basic principles of technological neutrality, proportionality and integrity, and promotion of technological innovation. So, the Commission on Technological Innovation in

Table 2

Directions and subjects of influence of fintech

\begin{tabular}{|c|c|c|c|}
\hline \multirow{6}{*}{ 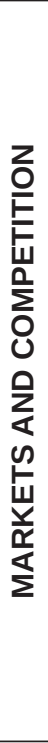 } & & \multicolumn{2}{|c|}{ CLIENTS' EXPERIENCE WITH NEW FINANCIAL SERVICES } \\
\hline & & $\begin{array}{l}\text { Improving the customer experience } \\
\text { with new products, new services } \\
\text { and new functionality }\end{array}$ & $\begin{array}{l}\text { Complement customer experience with } \\
\text { enhancements to existing functionality }\end{array}$ \\
\hline & \multicolumn{3}{|c|}{ "Explosive" effects from } \\
\hline & $\begin{array}{l}\text { New business models. New } \\
\text { market mechanisms. } \\
\text { Separate technological } \\
\text { infrastructure. } \\
\text { Disintermediation of banks. } \\
\text { Individual marketing ("one-person } \\
\text { segment"). } \\
\text { Cross-border innovation. }\end{array}$ & $\begin{array}{l}\text { blockchain-based markets, ICO, } \\
\text { cryptocurrency, international money } \\
\text { transfers, high-frequency trading, } \\
\text { crowdfunding, P2P lending, online } \\
\text { brokerage, cross-border payments, } \\
\text { open banking }\end{array}$ & $\begin{array}{l}\text { Open banking / API, accelerated } \\
\text { settlement of payments, more efficient } \\
\text { settlement thanks to blockchain, smart } \\
\text { contracts in trading and crediting } \\
\text { services, cross-border customs } \\
\text { services, payment cards with improved } \\
\text { functionality }\end{array}$ \\
\hline & \multicolumn{3}{|c|}{ Complementary effects from } \\
\hline & $\begin{array}{l}\text { Improving business models. } \\
\text { Advanced access for customers. } \\
\text { Hybrid services from companies. } \\
\text { Separate technological } \\
\text { infrastructure. } \\
\text { Open APIs. }\end{array}$ & $\begin{array}{l}\text { Social trading, digital wallets, robo- } \\
\text { advising, banking without branches, } \\
\text { personal financial management }\end{array}$ & $\begin{array}{l}\text { Investor community, mobile payments, } \\
\text { blockchain-based shared registry } \\
\text { functionality, risk management } \\
\text { technologies, regtech, remote deposit } \\
\text { opening, fintech trading support }\end{array}$ \\
\hline
\end{tabular}


the field of financial services of the EU determines that:

- technology-neutral to ensure that the same activity is subject to the same regulation irrespective of the way the service is delivered, so that innovation is enabled and level-playing field preserved;

- proportional, reflecting the business model, size, systemic significance, as well as the complexity and cross-border activity of the regulated entities;

- integrity-enhancing, as application of technologies to financial services should promote more market transparency to the benefit of consumers and businesses without creating unwarranted risks (e.g. market abuse, misselling, cyber security issues, systemic risks) [6].

To adapt the institutional framework to the functioning of the FinTech Industry and new financial products using financial technology, the new institutional tool was used for the first time in the UK, it was the regulatory sandbox. Regulatory sandbox is a special legal regime that allows legal entities involved in the development of new financial products and services to conduct experiments in a limited environment for their implementation without risk of violation of the current legislation [7]. The work of the regulatory sandbox can reduce the legal uncertainty and legal risks for participants in the financial market. This is due to the fact that current legislation and regulation do not always and fully take into account the features of new financial decisions. According to the results of the experiment, rules for new technologies are being formed in the regulatory sandbox. The regulatory sandbox allows you to accelerate the emergence of new solutions to the market. Currently, 13 regulatory "sandboxes" are actively working in the world with real cases, namely in the USA, Britain, Canada, Australia, Switzerland, Singapore, Lithuania, UAE, Malaysia, Philippines, Thailand, Indonesia. Almost as many are still being developed or are in the planning stages before launch.

Particular attention deserves technological solutions that increase the efficiency of work and reduce the cost of doing business by financial institutions - RegTech (regulatory technologies). Regulatory Technology or RegTech help companies, organizations and corporations meet the new regulatory requirements and regulate their implementation. Reverse Technologies for Financial Regulators - SupTech (Supervisory Technologies). SupTech involves the use of innovative technologies (big data, machine learning, artificial intelligence, cloud technologies, etc.) to improve the processes of response and supervision of financial market participants. These technologies allow financial regulators to automate and simplify administrative procedures, transfer data and tools to interact with financial market participants in digital format, improve the reliability and quality of reporting information and improve the decision support system.

The digital transformation of society is becoming a key factor that affects literally all social processes, everyday and - fundamental - global. The experience of developed countries shows that point-and-need efforts for the full implementation of digitalization are absolutely insufficient, so a coherent strategy is needed.

The FinTech Circle study (a global platform bringing together more than 130,000 FinTech entrepreneurs, investors, finance professionals, academics and government providers and decision providers), which is based on a survey of platform participants and experts identifies a number of trends in the FinTech industry taking into account different approaches to its systematization. Thus, there is a steady increase in investment in the industry, the predominance of the principle of "less promises more action (for monetization of ideas and increased cash flow), increasing the role of data analytics and security, activation of traditional financial intermediaries to maintain their positions, evolutionary development of artificial intelligence, further development of Legaltech (for contracting), growth of Open Banking opportunities, expansion of Paytech (not limited to B2C solutions), establishment of cross-country cooperation - "FinTech bridges" (cooperation agreements between governments that create a link between two markets and ecosystems, for example, such as the United Kingdom and China) [8].

Regarding the prospects for development, analysts identify a number of opportunities: the gradual abandonment of physical interfaces in favor of voice control and visual authentication; use of virtual reality technologies; output of the level of computing power to a completely new level (possible use of quantum computing); the FinTech segment will form a new business model; the economy of shared consumption will become an integral part of the financial system; the blockchain will cause a radical restructuring of the industry; digital format will become the main one; customer data analytics will be the main tool for forecasting revenue growth and profitability; the public cloud will become the main model of infrastructure; cybersecurity threats will become one of the main risks for financial institutions; regulators will also pay more attention to technology.

Ukraine has taken the first steps in this direction the Concept for the Development of the Digital Economy and Society of Ukraine for 2018-2020 and the plan of measures for its implementation have been approved, the last one is a document outlining the principles of Ukraine's development in digital space, which is the basis for the development of digital the economy [9]. However, the relevant program document in the EU was adopted in 2010, and given 
the speed of the emergence and dissemination of innovation, it is necessary to act as a proactive measure. Also, the Strategy for the development of fintech in Ukraine until 2025 is being implemented. [10]. On the basis of international experience on the functioning of regulatory "sandbox" were implemented approaches to develop the most appropriate model innovation facilitator, test launch of Sandbox by the National Bank in Ukraine is planned for December 2021, full launch is planned for the second half of 2022 [11].

In Ukraine, the FinTech industry is actively developing. The research of the Finnish-sector of Ukraine carried out within the framework of the USAID Transformation of the Financial Sector Project has made it possible to distinguish the following trends:

- $40 \%$ of the FinTech companies that took part in the study were established by 2015 , while other $60 \%$ appeared in the last three years. About $84 \%$ of FinTech companies have already started offering products and services;

- financing is a major problem. $45 \%$ of FinTech companies use equity to finance their operating activities (without attracting foreign investment); 49\% of companies have financing or are looking for foreign investors; the need for investments in the Ukrainian FinTech sector is estimated by the players of the market at 40-75 million USD;

- the areas of specialization of Ukrainian FinTech companies are payments and remittances (31.6\% of all companies), investments in technology and infrastructure (19.3\%), lending (14\%), marketing (7\%), other equipment (5.3\%), digital banks [12].

The world is changing dramatically under the influence of new challenges, both constructive in the context of innovation and destructive in the context of the COVID-19 pandemic. This requires a serious deepening of the experience in the digital environment, which is achieved through the further development of Fintech. Fintech has demonstrated its potential to address gaps in the provision of financial services to households and firms in emerging and developed markets.

At the start of the COVID-19 crisis, the financial industry demonstrated its flexibility, scalability, and efficiency by quickly launching targeted products and services that helped to adapt to the government's restrictive measures. However, the economic consequences of the coronavirus have affected many projects and significantly affected financial markets and fines in particular. The economic downturn after COVID-19 could create a situation where concerned customers will prefer to use the services of larger and established suppliers, such as large banks.

A pandemic, like any other crisis, has created not only problems but also opportunities. E-commerce has grown, which has changed consumer behavior, the preconditions for the formation of a cashless economy have been created, now there is a need for remote identification technologies and biometric solutions - all these moments are positive consequences of quarantine. Solutions such as information security, scoring, RegTech and SupTech and a number of others are becoming drivers of growth for FinTech amid change. But in general, our economy is in a state of uncertainty: no one knows when the pandemic will finally end and the outflow to normal life will begin.

Conclusions. As a result of the study, it can be concluded that in the context of the digital transformation of economic systems more rapidly the corresponding technological advances are introduced into the activity of the financial sector, changing both the composition, structure and principles of the activities of financial institutions, and influencing through changes in the financial system on the structural components of the economic system in general. Thus, changes take place at all levels of economic aggregation through the whole set of links between economic entities - coordination, re-ordination and subordination. The digitalization of the economy and the introduction of innovations are highly relevant for further stabilization.

The development of financial technologies leads to the emergence of a new financial infrastructure; causes the blurring of the boundaries of economic activity, the emergence of new markets and new forms of their functioning; promotes the introduction of new business models (marketplaces, ecosystems), new forms in which financial products are offered and sold; allows you to create new channels of customer interaction and new models of accelerated customer experience (digital customer experience); provides new regulatory tools and methods for complying with financial institutions and companies. Consequently, the changes resulting from the introduction of innovations in the co-operation of technologyfinance-institutions cover the entire reproduction process, which necessitates further research in the field of institutional changes in the economic system of society as a whole and the financial system in particular.

\section{REFERENCES:}

1. Digital Planet 2017: How Competitiveness and Trust in Digital Economies Vary Across the World. Available at: https://sites.tufts.edu/digitalplanet/executive-summary (accessed 02 February 2021).

2. Beyond Fintech: A Pragmatic Assessment of Disruptive Potential in Financial Services. (n.d.). weforum.org. Available at: https://www.weforum.org/reports/beyond-fintech-a-pragmatic-assessment-ofdis-ru-ptive-potential-in-finan-cialservices (accessed 3 February 2021).

3. Christensen Clayton M., Raynor Michael E., McDonald Rory (2015) What Is Disruptive Innovation? 
Harvard Business Review. Available at: https://hbr.org/ 2015/12/what-is-disruptive-innovation (accessed 01 February 2021).

4. Pochenchuk H.M. (2016) Instytutsionalnyi rozvytok ekonomiky $v$ umovakh finansovoi hlobalizatsii [Institutional development of the economy in the conditions of financial globalization]. Kyiv: «Tsentr uchbovoi literatury». (in Ukrainian)

5. Pulse of Fintech $\mathrm{H} 2$ 2019. Available at: https://assets.kpmg/content/dam/kpmg/xx/pdf/2020/02/ pulse-of-fintech-22019.pdf (accessed 05 February 2021).

6. Public consultation on FinTech: a more competitive and innovative European financial sector. Available at: https://ec.europa.eu/info/finance-consultations-2017fintech_en (accessed 07 February 2021).

7. Financial Conduct Authority. Regulatory sandbox lessons learned report. Available at: https://www.fca.org.uk/ publication/research-and-data/regulatory-sandboxlessons-learned-report.pdf (accessed 09 February 2021).

8. Fintech Trends 2020. Available at: https://fintechcircle.com/fintech-trends-2020/ (accessed 08 February 2021).

9. Pro skhvalennia Kontseptsii rozvytku tsyfrovoi ekonomiky ta suspilstva Ukrainy na 2018-2020 roky ta zatverdzhennia planu zakhodiv shhodo yii realizatsii Kabinet Ministriv Ukrainy; Rozporiadzhennia vid 17.01.2018 \# 67 r. [On approval of the Concept of development of the digital economy and society of Ukraine for 2018-2020 and approval of the action plan for its implementation by the Cabinet of Ministers of Ukraine; Order dated January 17, 2018 № 67]. Available at: http://zakon5.rada.gov.ua/laws/show/67-2018-\%D1\% 80/page1 (accessed 09 February 2021).

10. Stratehiia rozvytku fintekhu v Ukrani do 2025 roku [Strategy of fintech development in Ukraine until 2025. Available at: https://bank.gov.ua/ua/about/develop-strategy/fintech2025 (accessed 07 February 2021).

11. Kontsept platformy innovatsiinykh finansovykh rishen NBU [The concept of the platform of innovative financial solutions of the NBU]. Available at: https://bank.gov.ua/admin_uploads/article/Finteh2025_ pisochnycja.pdf?v=4 (accessed 09 February 2021).

12. Proekt USAID «Transformatsiia finansovoho sektoru» ta UNIT. City prezentuvaly pershe doslidzhennia fintekh-sektoru v Ukraini [USAID Financial Sector Transformation Project and UNIT. City presented the first study of the fintech sector in Ukraine]. Available at: http:// ufuture.com/uk/proekt-usaidtransformatsiya-fi-nansovogosektoru-ta-unitcity-prezentuvali-pershe-do-slidzhennyafinteh-sektoru-v-ukrayini/ (accessed 10 February 2021).

13. FinTech-startapy v Ukraini. Koly chekaty na «zelene svitlo»? [FinTech-startups in Ukraine. When to wait for the «green light»?]. (n.d.). News.finance.ua. Available at: https://news.finance.ua/ua/news/-/414020/ fintech-startapyv-ukrayini-koly-chekaty-zelene-svitlo 03.11.2017 (accessed 11 February 2021).

\section{БІБЛІОГРАФІЧНИЙ СПИСОК:}

1. Digital Planet 2017: How Competitiveness and Trust in Digital Economies Vary Across the World. URL: https://sites.tufts.edu/digitalplanet/executive-summary/ (дата звернення: 02.02.2021).

2. Beyond Fintech : A pragmatic assessment of disruptive potential in financial services. URL: https://www.weforum.org/reports/beyond-fintech-apragmatic-assessment-of-disruptive-potential-in-financial-services (дата звернення: 03.02.2021).

3. Christensen Clayton M., Raynor Michael E., McDonald Rory. What Is Disruptive Innovation? Harvard Business Review. URL: https://hbr.org/2015/12/ what-is-disruptive (дата звернення: 01.02.2021).

4. Поченчук Г.М. Інституціональний розвиток економіки в умовах фрінансової глобалізації: монографрія. Київ : «Центр учбової літератури», 2016. $420 \mathrm{c}$.

5. Pulse of Fintech $\mathrm{H}_{2}$ 2019. URL: https://assets. $\mathrm{kpmg} /$ content/dam-/kpmg/xx/pdf/2020/02/pulse-of-fintech-h2-2019.pdf/ (дата звернення: 05.02.2021).

6. Public consultation on FinTech: a more competitive and innovative European financial sector. URL: https://ec.europa.eu/info/finance-consultations-2017 -fintech_en (дата звернення: 07.02.2021).

7. 7. Financial Conduct Authority. Regulatory sandbox lessons learned report. URL: https ://www.fca.org.uk/ publication/research-and-data/regulatory-sandbox-lessons-learned-report.pdf (дата звернення: 09.02.2021).

8. Fintech Trends 2020. URL: https://fintechcircle. com/fintech-trends-2020/ (датазвернення: 08.02.2021).

9. Про схвалення Концепції розвитку цифрової економіки та суспільства України на 2018-2020 роки та затвердження плану заходів щодо іï реалізації Кабінет Міністрів України; Розпорядження від 17.01.2018 № 67 p. URL: http://zakon5.rada.gov.ua/ laws/show/67-2018-\%D1\%80/page (дата звернення: 09.02.2021).

10. Стратегія розвитку фрінтеху в Україні до 2025 року. URL: https://bank.gov.ua/ua/about/develop-strategy/fintech2025 (дата звернення: 07.02.2021).

11. Концепт платформи інноваційних фінансових рішень НБУ. URL: https://bank.gov.ua/admin_uploads/ article/Finteh2025_pisochnycja.pdf?v=4 (дата звернення: 09.02.2021).

12. Проект USAID «Tрансорормація фрінансового сектору» та UNIT.City презентували перше дослідження фрінтех-сектору в Україні. URL: http://ufuture.com/ uk/proekt-usaidtransformatsiya-finansovogo-sektoru-taunitcity-prezentuvali-pershe-doslidzhennya-finteh-sektoru-v-ukrayini/ (дата звернення: 10.02.2021).

13. FinTech-стартапи в Україні. Коли чекати на «зелене світло»? URL: https://news.finance.ua/ ua/news/-/414020/fintech-startapy-v-ukrayini-kolycheka-ty-zelene-svitlo 03.11.2017 (дата звернення: 11.02.2021). 